\title{
The Relationship Between Ritual Activities and Tendency to Depression in Elderly
}

\author{
Diah Septiani $^{1 *}$, Sambodo Sriadi Pinilih ${ }^{1}$, Retna Tri Astuti ${ }^{1}$ \\ ${ }^{1}$ Department of Nursing Science, Faculty of Health Science, Universitas Muhammadiyah Magelang, Magelang, \\ Indonesia \\ ${ }^{*}$ Corresponding author. Email: diiah.septianny@gmail.com
}

\begin{abstract}
Depression is a common problem in elderly and recognized as a life-threatening mental health problem in Indonesia. The initial study at Gelangan Village, Magelang city exposed the depression is currently being a concern in elderly population. Even though a number of depression studies were undertaken, however, a relevant and promising study that conducted in Gelangan Village has received little attention from the nurse researcher particularly in scrutinizing the religious aspect of depression. Thus, the study was initiated to figure out the relationship between ritual activities and tendency to depression in elderly. The study aimed at examining the relationship between ritual activities and the tendency to depression in elderly at "Posyandu Lansia Ngudi Rahayu" in Gelangan Village, Magelang City. Correlational design that combined with the cross-sectional method was thoughtfully chosen to answer the research question of the study. During April 2019 to May 2019, a total of 40 respondents were involved. In this study, two variables were selected as follows ritual activities (variable one) and tendency to depression (variable two). The Spearman's rank correlation was taken into consideration to measures the strength and direction of the relationship between variables. The significance level was considered at 0.05 for hypothesis testing. The finding of the study showed that the relationship between ritual activities and tendency to depression is statistically significant ( $\mathrm{p}$ $<0.05)$. Moreover, the level of correlation is fair as expected by the researcher $(-0.448)$. The negative correlation was also obtained that is to say when the variable one increases, the other decreases. The relationship between ritual activities and tendency to depression is statistically significant $(\mathrm{p}<0.05)$. Ritual activities seems to be an appropriate treatment which can be integrated into clinical workflow management of depression care in elderly.
\end{abstract}

Keywords: ritual activities, tendency, depression, elderly

\section{INTRODUCTION}

Depression is a common mental health problem in elderly that potentially affect health-related quality of life. If left untreated, depression may also lead to devastating consequences at any given time particularly in a community setting [4,14,2,5]. World Health Organization (WHO) recorded the prevalence rate of depression in elderly varies between $10-20 \%$ [3].

In Indonesia, depression is also being a concern in elderly group due to those who received treatment has reached only $9 \%$ from all the sufferers [3]. What's more, in small-scale survey research, Prof. Dr. Soeroyo Psychiatric Hospital exhibited several cases of depression in elderly as follows: one person is classified in severe depression, six persons were classified in mild depression, and four persons were also suffering physical health problem [16]. In addition, a preliminary study performed by researchers in Gelangan Village showed evidence of depression in elderly. This phenomena caused by some elderly spend most of their time at home and no productive activities fulfilled. Likewise, several elderly also experienced limitations in doing Activities Daily Living (ADL) and have a medical condition such as hypertension and diabetes. When receiving insufficient attention and management, these conditions may lead to depression.

With a progressively aging population suffering depression, identification and treatment of depression become increasingly important. A titanic amount of depression studies were undertaken, however, to date, a relevant study that conducted in Gelangan Village has received little attention from the nurse researcher particularly in scrutinizing the religious aspect of depression. Also, questions have arisen about the role of ritual activities in depression care in elderly. To explore this association, this study was initiated and focused on describing the relationship between ritual activities and tendency of depression in elderly.

\section{METHOD}

The study used non-experimental design as it lacks the manipulation of an independent variable, random assignment of participants to conditions or orders of conditions, or both $[13,12]$. Correlational design between two variables (ritual activities and tendency of depression) were considered [17]. To gain real-time patient's data, the cross-sectional method was applied due to the study will 
collect the data at one given point of time across a sample population [7].

Utilizing a survey method, a theoretical purposive sample of forty people participated in this study. The criteria and the characteristics of a population and the objective of the study (purposive sampling) were also determined [16]. The inclusion criteria refer to:
a. Respondent who aged $60-75$ years old
b. Respondent who were categorized in mild and moderate depression
c. Respondent who signed the inform consent letter
d. We then also excluded the respondent when they have criteria as mentioned below:
e. Respondent with hearing problem without using hearing aid
f. Respondent with speech disorders
g. Respondent with Dementia and Alzheimer
By considering the strength and weaknesses of the study, we expected a fair correlation coefficient $(0.430)$ between variables [1].

\section{RESULT AND DISCUSSION}

\subsection{Characteristics of respondents}

Table 1. Age characteristic

\begin{tabular}{|cccc|}
\hline No & Age & Total & Percentage \\
\hline 1 & $60-65$ years & 25 & $62.5 \%$ \\
2 & $66-70$ years & 7 & $17.5 \%$ \\
3 & $71-75$ years & 8 & $20 \%$ \\
\hline & Total & $\mathbf{4 0}$ & $\mathbf{1 0 0} \%$ \\
\hline
\end{tabular}

Table 2. Sex characteristic

\begin{tabular}{|clcc|}
\hline No & \multicolumn{1}{c}{ Sex } & Total & Percentage \\
\hline 1 & Female & 31 & $77.5 \%$ \\
2 & Male & 9 & $22.5 \%$ \\
\hline \multicolumn{2}{r}{ Total } & $\mathbf{4 0}$ & $\mathbf{1 0 0} \%$ \\
\hline
\end{tabular}

Table 3. Religion characteristic

\begin{tabular}{|cccc|}
\hline No & Religion & Total & Percentage \\
\hline 1 & Islam & 31 & $77.5 \%$ \\
2 & Christian & 6 & $15.0 \%$ \\
3 & Catholic & 3 & $7.5 \%$ \\
\hline & Total & $\mathbf{4 0}$ & $\mathbf{1 0 0} \%$ \\
\hline
\end{tabular}

Table 4. Education level

\begin{tabular}{|cccc|}
\hline No & Education level & Total & Percentage \\
\hline 1 & Elementary School & 23 & $57.5 \%$ \\
2 & Junior High School & 8 & $20.0 \%$ \\
3 & Senior High School & 5 & $12.5 \%$ \\
4 & Uneducated & 4 & $10.0 \%$ \\
\hline & Total & $\mathbf{4 0}$ & $\mathbf{1 0 0} \%$ \\
\hline
\end{tabular}

Table 5. Job characteristic

\begin{tabular}{|cccc|}
\hline No & Job & Total & Percentage \\
\hline 1 & Housewife & 18 & $45.5 \%$ \\
2 & Others (trader, & 9 & $22.5 \%$ \\
& freelancer, driver) & & \\
3 & Labourer & 6 & $15.0 \%$ \\
4 & Pensioner & 5 & $12.5 \%$ \\
5 & Joblessness & 2 & $5.0 \%$ \\
\hline & Total & 40 & $100 \%$ \\
\hline
\end{tabular}

Table 6. Characteristic of ritual activities

\begin{tabular}{|cccc|}
\hline No & Ritual activities & Total & Percentage \\
\hline 1 & High & 29 & $72.5 \%$ \\
2 & Moderate & 11 & $27.5 \%$ \\
3 & Low & 0 & 0 \\
\hline & Total & 40 & $100 \%$ \\
\hline
\end{tabular}

Table 7. Characteristic of tendency of depression

\begin{tabular}{|cccc|}
\hline No & $\begin{array}{c}\text { Tendency of } \\
\text { depression }\end{array}$ & Total & Percentage \\
\hline 1 & Normal & 25 & $62.5 \%$ \\
2 & Mild & 15 & $37.5 \%$ \\
3 & Moderate & 0 & 0 \\
4 & Severe & 0 & 0 \\
\hline & Total & 40 & 100 \\
\hline
\end{tabular}

\subsection{The relationship between ritual activities and tendency to depression}

Table 8. Relationship between ritual activities and tendency to depression

\begin{tabular}{|cccccc|}
\hline Ritual & \multicolumn{4}{c}{ Tendency to depression } & \multirow{2}{*}{ Total } \\
\cline { 2 - 5 } activities & Normal & Mild & Moderate & Severe & \\
\hline High & 22 & 7 & 0 & 0 & 29 \\
Moderate & 3 & 8 & 0 & 0 & 11 \\
Mild & 0 & 0 & 0 & 0 & 0 \\
\hline Total & 25 & 15 & 0 & 0 & 40 \\
\hline
\end{tabular}

Table 9. Statistical analysis

\begin{tabular}{|c|c|c|}
\hline Variables & $\boldsymbol{r}$ & $p$-value \\
\hline Ritual activities & & \\
\hline Tendency of depression & -0.448 & 0.004 \\
\hline
\end{tabular}

A statistically significant correlation was found between ritual activities and tendency of depression in elderly $(\mathrm{p}<$ $0.05)$. The type of correlation is negative and the level of correlation is fair $(-0.448)$.

\subsection{Ritual activities}

The findings of this study provide evidence that the majority of respondent are classified in a high level of ritual activities (29 respondents; $72.5 \%$ ) and a moderate level of ritual activities (11 respondents; $27.5 \%$ ). Interestingly, there is no such respondent who classified in a low level of ritual activities. 


\section{CONCLUSIONS}

Through the research process, those who classified in a high level of ritual activities attend religious activities every week. In addition, some of them engaged more than three times a week. It is also known from this study that most of the respondents received information with regard to religious activities from television and radio.

On the other hand, several respondents were in a moderate level of ritual activities (27 respondents; $27.5 \%$ ). They are unable to participate in such activities due to they have to work either have some diseases (hypertension and diabetes).

\subsection{Tendency to depression}

This study revealed that most of the respondents are normal which means none of depressive symptoms found (25 respondents; $62.7 \%$ ). However, a total of 15 elderly $(37.5 \%)$ are classified in mild depression. Lack of organizational religious involvement and caregiver's support was acknowledged as the factors lead to mild depression in the population. Also, some of the respondents suffered diseases such as hypertension, diabetes, gout, and stroke which may potentially worsen depression.

Foregrounding this, behavioral activation are recommended for those who experience depression. This approach is designed to increase in enjoyable activities and positive reinforcement. Furthermore, it has been proved to be effective in reducing depression and improving healthy behavior in elderly [9].

Additionally, family support plays an important role to decrease the depressive symptoms to those people [18].

\subsection{The relationship between ritual activities and tendency to depression}

This study suggests that when ritual activities increases, tendency to depression decreases. Vice versa, when ritual activities decrease, tendency to depression increases. It means that religious aspect needs to be integrated into taking care of patients with depression.

A study supported that the influence of religion on health is generally positive, and gives a hopeful state of mind which may decrease tendency to depression [15].

In line with the purposes of depression treatment, Allah subhaanahu wa ta'ala stated: verily in the remembrance of Allah, do hearts find peace (QS. Ar Ra'd ayat 28). It means that depression is a normal part of life, which can be healed with prayer and patience. As is well known, people become depressed when they do not achieve what they want, but those who believe to Allah's help, are always happy although in terrible situation.

Religiously Integrated Cognitive Behavioural Therapy (RCBT) can also be applied. It is a therapeutic approach which designed to help individuals in reducing internal factors lead to depression by using their own beliefs and religious resources [8]. Religious Cognitive - Emotional Therapy (RECT) has effectiveness to overcome various psychological problems including depression [10].
We highlighted a statistically significant correlation between ritual activities and tendency of depression in elderly $(\mathrm{p}<0.05)$. The type of correlation is negative and the level of correlation is fair $(-0.448)$. Ritual activities seems to be an appropriate treatment which can be integrated into clinical workflow management of depression care in elderly.

\section{ACKNOWLEDGMENT}

Diah Septiani, as the lead author, extends heartfelt gratitude for those who entirely gave their love and care during the research process such as her beloved parents, research advisors, and classmate in Bachelor of Science in nursing cohort 2015.

\section{REFERENCES}

[1] Akoglu, H. (2018). User's guide to correlation coefficients. Turkish Journal of Emergency Medicine, 18(3), 91-93.

[2] Frank, C. (2014). Pharmacologic treatment of depression in the elderly. Canadian Family Physician Medecin de Famille Canadien, 60(2), 121-126.

[3] Grover, S., Sahoo, S., Chakrabarti, S., \& Avasthi, A. (2018). Anxiety and somatic symptoms among elderly patients with depression. Asian Journal of Psychiatry, 5(July), $0-1$.

[4] Hendry, I. (2013). Gangguan Depresi pada Lanjut Usia. Cermin Dunia Kedokteran, 40(11), 815-819.

[5] Holm, A. L., Lyberg, A., \& Severinsson, E. (2014). Living with stigma: depressed elderly persons' experiences of physical health problems. Nursing Research and Practice, 2014, 527920.

[6] Palinkas, L. A., Horwitz, S. M., Green, C. A., Wisdom, J. P., Duan, N., \& Hoagwood, K. (2015). Purposeful Sampling for Qualitative Data Collection and Analysis in Mixed Method Implementation Research. Administration and Policy in Mental Health, 42(5), 533-544.

[7] Parab, S., \& Bhalerao, S. (2010). Study designs. International Journal of Ayurveda Research, 1(2), 128131.

[8] Pearce, M. J., Koenig, H. G., Robins, C. J., Nelson, B., Shaw, S. F., \& King, M. B. (2015). Religiously Integrated Cognitive Behavioral Therapy: A New 
(E. V. Manullang, Ed.) (Edisi 1). Jakarta: Pusat Data Dan Informasi Kemenkes RI.

With Chronic Medical Illness. Psychoterapy

(Chic),52(1), 56-66.

[9] Polenick, C. A., \& Flora, S. R. A. Y. (2013).

Behavioral Activation for Depression in Older Adults :

Theoretical and Practical Considerations. The Behavior Analyst, 1(1), 35-55.

[10] Rajaei, A. R. (2010). Religious Cognitive Emotional Therapy : A New Form of Psychotherapy. Iranian Journal of Psychiatry, (17), 81-87.

[11] Riskesdas. (2018). Riskesdas Launching 2018. Jakarta: Badan Penelitian Dan Pengembangan Kesehatan.

[12] Süt, N. (2014). Study designs in medicine. Balkan Medical Journal, 31(4), 273-277.

[13] Toledo-Pereyra, L. H. (2012). Research Design. Journal of Investigative Surgery, 25(5), 279-280.

[14] Turana, Yuda, Abikusno, Nugroho, Santika, A. (2013). Gambaran Kesehatan Lanjut Usia Di Indonesia.
[15] Vasegh, S., Rosmarin, D. H., Koenig, H. G., Dew, R. E., \& Bonelli, R. M. (2012). Religious and Spiritual Factors in Depression. Depression Research and Treatment, 2012, 3-5.

[16] RSJ Magelang. (2018). Lansia, Masa Depan Bahagia. Retrieved from https://rsjsoerojo.co.id/2018/08/31/lansia-masa-depanbahagia/ (Accessed 24 September 2019).

[17] Lau, F. (2017) Chapter 12. Methods for Correlational Studies. In: Lau F, Kuziemsky C, editors. Handbook of eHealth Evaluation: An Evidence-based Approach [Internet]. Victoria (BC): University of Victoria; 2017 Feb 27. Available from: https:/www.ncbi.nlm.nih.gov/books/NBK481614/ (Diakses 7 November 2018).

[18] Park, M., \& Unützer, J. (2011). Geriatric depression in primary care. The Psychiatric clinics of North America, 34(2), 469-x. doi:10.1016/j.psc.2011.02.009. 